\title{
Paneth cells: histochemical and morphometric study in control and Solanum glaucophyllum intoxicated rabbits
}

\author{
C.N. Zanuzzi ${ }^{1,2}$ P.A. Fontana, ${ }^{1}$ C.G Barbeito, ${ }^{1,2}$ E.L. Portiansky, ${ }^{1}$ E.J. Gimeno ${ }^{1}$ \\ ${ }^{1}$ Institute of Pathology Prof. Dr. Bernardo Epstein; ${ }^{2}$ Department of Histology and Embryology, \\ School of Veterinary Sciences, National University of La Plata, La Plata, Buenos Aires, Argentina
}

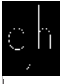

(C)2008 European Journal of Histochemistry

The intestinal epithelium has a critical roll in host defence. One specialised cell type involved in this function is the Paneth cell, which secretes many substances with antimicrobial properties in response to different stimuli. Under pathological conditions, changes in the Paneth cell number, morphology and location as well as in granule number, morphology and composition have been reported.

In the normal animal, 1,25-dihydroxyvitamin D3 participates in the maintenance of mineral homeostasis, immunomodulation and cell proliferation and differentiation. Solanum glaucophyllum, a calcinogenic plant containing high levels of 1,25-dihydroxyvitamin D3, is responsible for a condition known as enzootic calcinosis in ruminants, characterised by loss of body condition and mineralization of soft tissues. Using and established rabbit model, this study analyses the changes that rabbit Paneth cells undergo during intoxication with S. glaucophyllum. Male New Zealand white rabbits were experimentally intoxicated with S. glaucophyllum for 15 or 30 days. Lectin, immunohistochemical and morphometric studies were carried out on Paneth cells from samples of jejunum. SBA, DBA and WGA lectins bound to Paneth cellsgranules in both normal and intoxicated rabbits, with more heterogenity in the labelling of granules from intoxicated rabbits. Paneth cells in both groups were immunonegative for lysosyme. A time and dose-dependent increase in the size and number of Paneth cells was found in both intoxicated groups. We suggest that the changes described in these cells may be directly or indirectly induced by S. glaucophyllum intoxication.

Key words: Intestine, plant-induced hypervitaminosis $D_{3}$, morphometry, immunohistochemistry; lectinhistochemistry.

Correspondence: Eduardo Gimeno,

Instituto de Patología, Facultad de Ciencias Veterinarias, UNLP Calle 60 y 1181900 La Plata, Argentina

Tel.: +54.221.4236663 x426.

Fax: +54.221 .4257980$

E-mail: ejgimeno@fcv.unlp.edu.ar

Paper accepted on February 22, 2008

European Journal of Histochemistry 2008; vol. 52 issue 2 (Apr-Jun): 93-100
W hile the intestinal epithelium traditionally functions in the digestion and absorption of nutrients, it also participates in host defence and the elimination of pathogens (Müller et al., 2005). One intestinal epithelial cell line which clearly contributes to intestinal mucosal defence is the Paneth cell. These cells are located at the bottom of the Lieberkühn glands in the small intestine in numerous vertebrates (Porter et al., 2002; Bevins, 2004). Although Paneth cells were discovered more than one hundred years ago, most of our knowledge about their biology was acquired in the last decades. These cells synthesize substances with antimicrobial properties, such as $\alpha$-defensins, lysozyme and phospholipase A2 (sPLA2) (Porter et al., 2002) in response to different stimuli. Paneth cells also protect the proliferative compartment, control the composition of endogenous flora, participate in the crypt formation and development, and also in processes of fagocytosis, digestion and detoxification (Porter et al., 2002; Bevins, 2004; Ouellette, 2005).

Histochemistry and morphological studies have been performed on Paneth cells of different species. Morphometric, morphologic, or quantitative aspects of Paneth cell have been published in the rat, mouse, guinea pig (Sinke and Geyer, 1968; Rodning et al., 1982), golden hamster, human (Ehrmann et al., 1990), squirrel (Toth, 1980) and horse (Takehana et al., 1998). Even though the existence of Paneth cells in ruminants has to be determined; Ergün et al., (2003) confirmed the existence of Paneth cells in the small intestine of sheep. Little, however, is known about rabbit Paneth cell (Pitha, 1968; Oestrich et al., 1970).

Solanum glaucophyllum (synonym S. malacoxyIon) is a calcinogenic plant responsible for the enzootic calcinosis of ruminants in South America, a disease that causes considerable economic losses in Argentina, Brazil and Uruguay (Worker and Carrillo, 1967; Puche and Bingley, 
1995). This plant contains high levels of 1,25dihydroxyvitamin $\mathrm{D}_{3}$ as glycoside derivatives in its leaves (Gil et al., 2007). Hydrolytic enzymes in intestinal, ruminal or other tissues or in the bacterial flora can cleave the sugar residue from the glycoside, releasing the steroidal fragment, in most cases 1,25 -dihydroxyvitamin $D_{3}$. This excess of vitamin $D$ hormone specifically stimulates the synthesis of mucosal calcium binding protein (CaBP) and calcium and phosphate absorption, producing hypercalcemia and/or hyperphosphatemia (Walling MW and Kinberg, 1975; Wasserman et al., 1976; Scheneider and Scheld, 1977; Mello, 2003).

In the normal state this hormone plays a central role in mineral homeostasis, immunomodulation, cell growth and differentiation (Bikle, 2007).

The chronic ingestion of $S$. glaucophyllum bypasses the normal mechanisms of calcium regulation and leads to soft tissue mineralization. Clinically, intoxicated animals present stiffness, painful gait, xyphosis, anorexia, loss of body condition, and in the most severe cases advance cachexia (Worker and Carrillo, 1967). Furthermore, diarrhoea and enhanced sensitivity to infectious disease has also been observed in $S$. glaucophyllum-intoxicated animals (Stevenson et al., 1976; Gimeno et al., personal communication). However, the mechanisms for these effects have yet to be elucidated.

In the normal intestine vitamin $D$ enhances the efficiency to absorb dietary calcium and phosphate (Bikle, 2007), as well as affecting enterocyte proliferation and differentiation (Suda et al., 1990; Menard et al., 1995; Holt et al; 2002); however, changes associated with hypervitaminosis $D$ have not been reported.

Since Paneth cells respond to changes in the local microenviroment with changes in number, size, shape, location, and modifications in granule number, morphology and composition (Lewin, 1969), we hypothesized whether a hypervitaminosis D state can induce some of the mentioned changes in rabbit Paneth cells.

The present work analyses Paneth cells morphologic, histochemical, and morphometric patterns and parameters of Paneth cells in control and $S$. glaucophyllum intoxicated rabbits.

\section{Materials and Methods}

\section{Animals}

Sixteen three months old New Zealand white male rabbits were used in this study. All animals were clinically healthy. They were fed with a standard diet free of calcinogenic substances and water ad libitum. All the procedures were carried out according to the Guide for the Care and Use of Laboratory Animals of the National Research Council (National Academy Press, 1996, Washington, USA).

\section{Intoxication with Solanum glaucophyllum}

Ten animals were experimentally intoxicated per os with $125 \mathrm{mg} /$ animal of powdered Sg leaves twice a week until sacrifice. Five of them were euthanized 15 days after the first dosing (I-15: 15 days post-intoxication), and the other five after another 15 days (I-30: 30 days post-intoxication). Six rabbits were used as controls. Two of them were euthanized at the beginning of the experiment, another two after 15 days and the last two, at day 30. The body weight of each animal was recorded weekly. Clinical signs were observed and recorded every day, during the entire study.

\section{Histological and histochemical studies}

Following sacrifice, three coronal samples of jejunum of each animal were harvested, rinsed in PBS, fixed in 10\% neutral buffered formalin and embedded in paraffin. Five $\mu \mathrm{m}$ sections were stained either with haematoxylin and eosin, Masson's trichrome or Periodic Acid Schiff (PAS) (Brancroft and Stevens, 1990).

\section{Lectin histochemistry}

After deparaffinization, $5 \mu \mathrm{m}$ slides were passed through a decreasing graded alcohol scale and incubated with $0.03 \% \mathrm{H}_{2} \mathrm{O}_{2}$ in methanol for 30 $\mathrm{min}$ at room temperature to inhibit endogenous peroxidase activity. Slides were then treated with bovine serum albumin (BSA, 1\% in PBS) for 30 min and incubated overnight with biotinylated lectins. The following lectins (Lectin Kit BK 1000, Vector Laboratories, Inc., Burlingame, CA, USA) with different carbohydrate specificity were used: Con-A (Concanavalia ensiformis, specifically binding $\alpha$-D-Man and $\alpha$-D-GIc); DBA (Dolichus 
biflorus, with binding specificity to $\alpha-D-G a l N A c)$; SBA (Glicine maximus, binding specificity to $\alpha$ D-GalNAc, $\beta$-D-galNAc and $\alpha$ and $\beta$-Gal); PNA (Arachis hypogea, that specifically binds $\beta-D-G a l$ and (1-3) GalNAC); RCA-1 (Ricinus communis1 , binding specificity $\beta-D-G a l$ and $\alpha-D-G a l)$; UEA-1 (Ulex europaeus- 1 , binding specificity $\alpha$ L-Fuc) and WGA (Triticum vulgaris, binding specificity $\alpha-D$ GIcNAc and NeuNAc) (Goldstein and Hayes, 1978; Yasui et al, 2006). The optimal lectin concentration was $30 \mu \mathrm{g} / \mathrm{mL}$ in PBS for all lectins, except for PNA (10 $\mu \mathrm{g} / \mathrm{mL})$. The horseradish peroxidase streptavidin SA-5704 (Vector Laboratories, Inc., Burlingame, CA, USA), used as a detection system, was incubated during 30 min. Slides were rinsed three folds in PBS during five min each time. Liquid 3,3'diaminobenzidine tetrahydrocloride (DAB) was used as chromogen (DakoCytomation, Carpinteria, CA, USA. Negative controls for lectin staining included exposure to horseradish-peroxidase and substrate medium without lectin. The dark, golden brown $D A B$ hydrogen peroxide reaction product showed the positively stained structures. Mayer's haematoxylin was used for counterstaining. The intensity of lectin binding was scored using a qualitative scale from 0 to 3 , being 0 : negative, 1: weak, 2: moderate and 3: strong. Lectin controls were performed by the addition of inhibitory sugars at a final concentration of $0.01 \mathrm{M}$.

\section{Immunohistochemistry}

Five $\mu \mathrm{m}$ sections were mounted on slides coated with $\gamma$-methacryloxypropyltrimethoxy-silane ( M 6514, Sigma) and passed through a decreasing graded alcohol scale and incubated with $0,03 \% \mathrm{H}_{2} \mathrm{O}_{2}$ in methanol for $30 \mathrm{~min}$ at room temperature to inhibit endogenous peroxidase activity. Slides were then rinsed twice in PBS and exposed to microwave antigen retrieval using a buffer citrate solution ( $\mathrm{pH}$ 6.0) (Taylor et al., 1996). Slides were then incubated with $1 \%$ BSA in PBS for 30 min. Incubation of the sections with a biotinylated rabbit polyclonal anti-human lysozyme antibody (Accurate Chemical and Scientific Corporation, Westbury, NY, USA), diluted either at 1:50, 1:100 or 1:200, was done overnight. The Horseradish Peroxidase streptavidin SA 704 (Vector Laboratories, Inc., Burlingame, CA, USA) used as a detection system was incubated during $30 \mathrm{~min}$. Slides were rinsed three folds in PBS during 5 min each time. The peroxidase was activated by $D A B$, incubated for 1 to 2 min. The dark, golden brown DAB hydrogen peroxide reaction product showed the positively stained structures. Positive controls for antilysozyme antibody included sections of rabbit lachrymal gland, jejunum of adult male $\mathrm{C} 3 \mathrm{H} / \mathrm{S}$ mice and human jejunum sections, the latter provided by the Department of Pathology of San Martin Hospital, La Plata, Argentina. Mayer's haematoxylin was used for counterstaining. The intensity of labelling was scored using a qualitative scale from 0 to 3, being 0: negative, 1: weak, 2: moderate and 3: strong. Controls for immunohistochemistry were performed by the incubation with appropriate buffer without primary antibody.

\section{Image analysis}

For morphometric analysis ten images of each sample section were captured from a microscope (Olympus BX61 system microscope, Tokyo, Japan) with an objective magnification of $40 \mathrm{X}$, through an attached digital video camera (EvolutionVF, QImaging, USA) and digitized with a 24 bits RGB TIFF format. The captured images were processed and analysed using the ImagePro Plus v6.2 program (Media Cybernetics, Silver Spring, MA, USA). The following parameters were evaluated to characterise Paneth cells: cell area, major and minor axis, aspect (ratio between major and minor axis), perimeter and roundness. Sixty randomly selected Paneth cells were analyzed per animal. Raw data was exported to a spreadsheet in order to perform statistical analysis.

Paneth cell number per crypt was also evaluated. For this purpose, images from H-E stained sections were captured with an objective magnification of 40X. Digital images were then analyzed using the Manual Tag function of the image analysis software. Fifty crypts per animal were evaluated, considering only those fully visible and perpendicular to the muscularis mucosae.

\section{Statistical analysis}

The ANOVA test was used to evaluate differences among groups. The Bonferroni test was used as a post hoc index. Significant differences were defined as those with $p<0.05$. 


\section{Results}

\section{Histology}

Paneth cells of control rabbits exhibit a pyramidal shape, a basal displaced spherical nucleus with a visible nucleolus and slightly eosinophilic stained cytoplasm. Paneth cells arranged in tight groups exhibit ill-defined cellular borders (Figure $1 \mathrm{a}-\mathrm{c}$ ). A heterogeneous population of secretory granules with heterogeneous size was recognized in some cells when stained with haematoxylin and eosin, Masson's trichrome and PAS techniques (Figure 1 d-e). No differences were found among Paneth cells of control groups euthanized at different times.

Paneth cells of intoxicated animals were more easily recognized and their cellular limits more clearly defined when stained with haematoxylin and eosin. They appeared more spherical, with more discrete cell borders, and had more abundant foamy eosinophilic cytoplasm, and an eccentric, flattened or spherical nucleus (Figure $1 \mathrm{f}-\mathrm{j}$ ).

\section{Lectin histochemistry}

The following lectins bound to Paneth cell granules in control animals: SBA, DBA and WGA. (Figure $2 \mathrm{a}, \mathrm{c}$ ). In general, granules showed a weak to moderate peripheral staining (arrows in inset Figure 2a). There was variability in stain intensity among the granules of a single cell, between cells in the same crypt and among crypts. WGA labelling intensity was generally weaker than other lectins.

In intoxicated animals the lectin binding pattern did not vary from that seen in control animals (Figure $2 \mathrm{~b}, \mathrm{~d}$ ), however, the labelling was more heterogeneous.

\section{Immunohistochemistry}

Control and intoxicated rabbit Paneth cell did not stain with polyclonal anti-lysozyme antibody (Figure $3 \mathrm{a}, \mathrm{b}$ ) while rabbit lachrymal gland epithelial cells and jejunal Paneth cells from human and mice jejunal were positively labelled.

\section{Morphometry}

Paneth cells in normal animals are classically described as pyramidal; this observation was corroborated by our morphometric analysis where the aspect of the cells was greater than 1.5 with a roundness tending to 1 (i.e circular). Paneth cells of intoxicated animals were more round and larger overall. While the cellular area of the I-15 group had a mean value that exceeded that of control Paneth cells by more than $40 \mu \mathrm{m}^{2}$, minor axis differences were only statistically significant between control and the I-30 group $(p<0.01)$. Values corresponding to the major axis and perimeter showed significant differences between control and the both intoxicated groups $(p<0.01)$. (Table 1 ).

There was a significant $(p<0.01)$ increase in the number of those cells in both intoxicated groups (Table 1).

\section{Discussion}

The small intestine is one of the target organs of vitamin $D_{3}$. This hormone has effects on mineral homeostasis, cell proliferation and differentiation and immunomodulation. In light of this actions, we investigate the possible effects of $\mathrm{Sg}$ on intestinal Paneth cell, a cell line that plays an important roll in the innate intestinal immunity. In this study we used a rabbit model which reproduced the ruminant illness of enzootic calcinosis (Dallorso et al., 2001).

The lectin binding pattern of Paneth cell granules has been previously characterised in different species, in which the presence of the following residues was demostrated: fucose, $\mathrm{N}$-acetyl galactosamine and $\mathrm{N}$-acetyl-glucosamine (Leis et al., 1997; Evans et al., 1994). In the present work, Paneth cell granules bound to WGA, SBA and DBA. This indicates that $N$-acetyl $\alpha-D$ galactosamine and $N$-acetyl- $\beta$-D-glucosamine or probably acetyl neuraminic acid residues are present in

Table 1. Morphometric analysis of Paneth cell.

\begin{tabular}{lcccccc}
\hline Groups & Paneth cell count & Area & Major axis & Minor axis & Aspect & Roundness \\
\hline Control & $4.28 \pm 0.33$ & $77.35 \pm 4.29$ & $12.73 \pm 0.36$ & $7.83 \pm 0.19$ & 1.62 & $34.49 \pm 0.97$ \\
I-15 & $5.33 \pm 0.69^{\#}$ & $120.78 \pm 8.32^{\text {a }}$ & $16.50 \pm 0.55^{\#}$ & $9.54 \pm 0.52$ & 1.72 & $4.25 \pm 0,01$ \\
l-30 & $5.23 \pm 0.27^{\#}$ & $150.28 \pm 21.7^{\text {a\# }}$ & $16.51 \pm 1.04^{\#}$ & $11.53 \pm 0.98^{\#}$ & 1.43 & $1.31 \pm 0,07$ \\
\end{tabular}

"Significant vs control ( $p<0.05)$; "Significant vs control ( $p<0.01)$; ${ }^{a}$ Remarkable foamy pattern. 

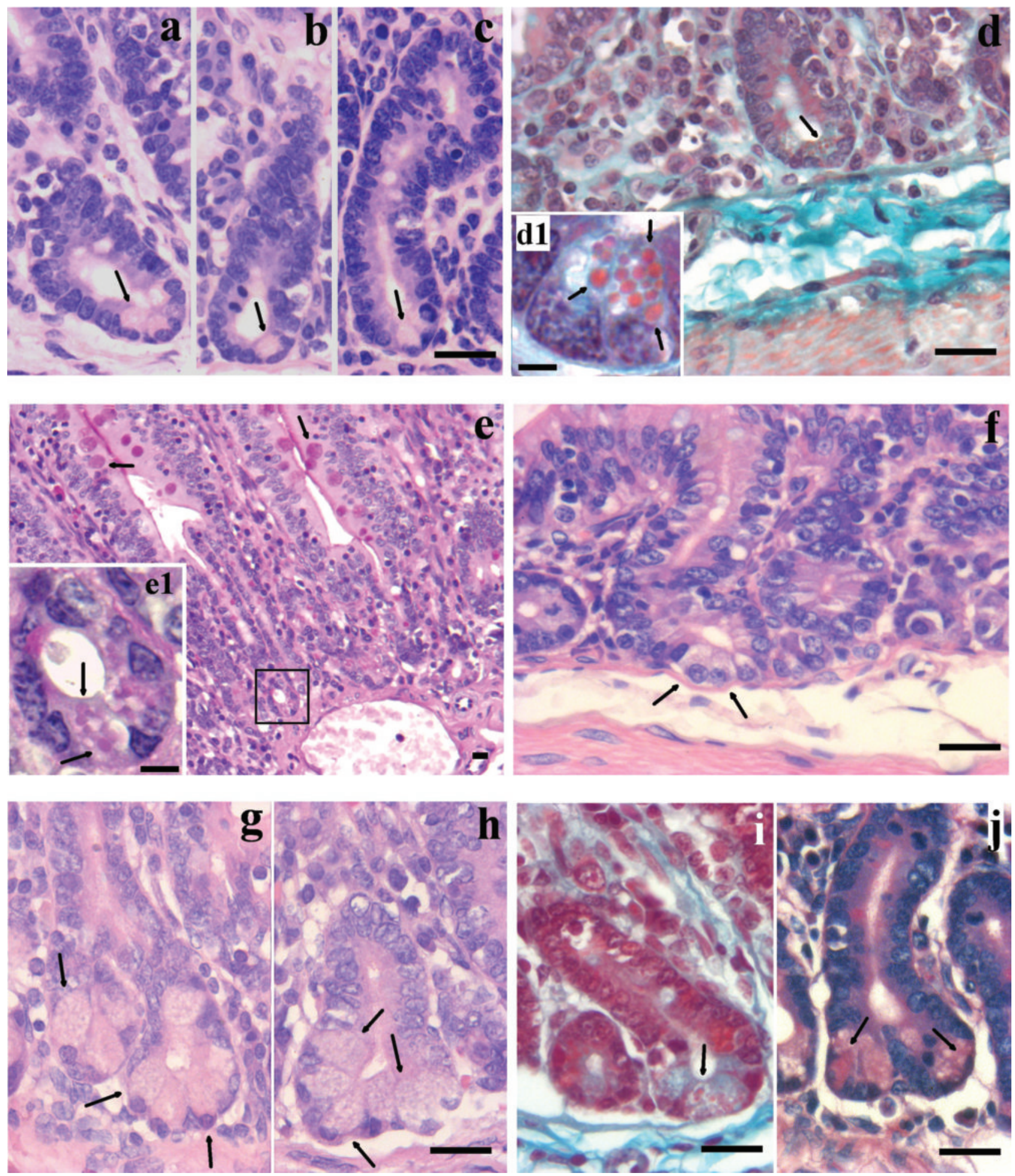

Figure 1. Histologycal and histochemical characterisation of control and intoxicated Paneth cell. (a-c). Control Paneth cell with not well defined intercellular boundaries (arrows). Haematoxyline-eosin staining. (d) Paneth cell granules stained red with Masson's trichrome technique (arrow). (d1) detail of the granules at higher magnification. Note the heterogeneous size (arrows). (e) PAS technique positively stains goblet cell premucin droplets as well as Paneth cell granules (square). (e1) detail of the PAS positive granules at higher magnification. (f) Paneth cell of I-15 group and I-30 group (g-h). Note the bigger size, more spherical shape, foamy cytoplasm and better defined intercellular boundaries (arrows). (i) Masson's trichrome and PAS techniques (j) in the I-30 Paneth cell group. Images bar = $10 \mu \mathrm{m}$. Inset bar $=5 \mu \mathrm{m}$. 

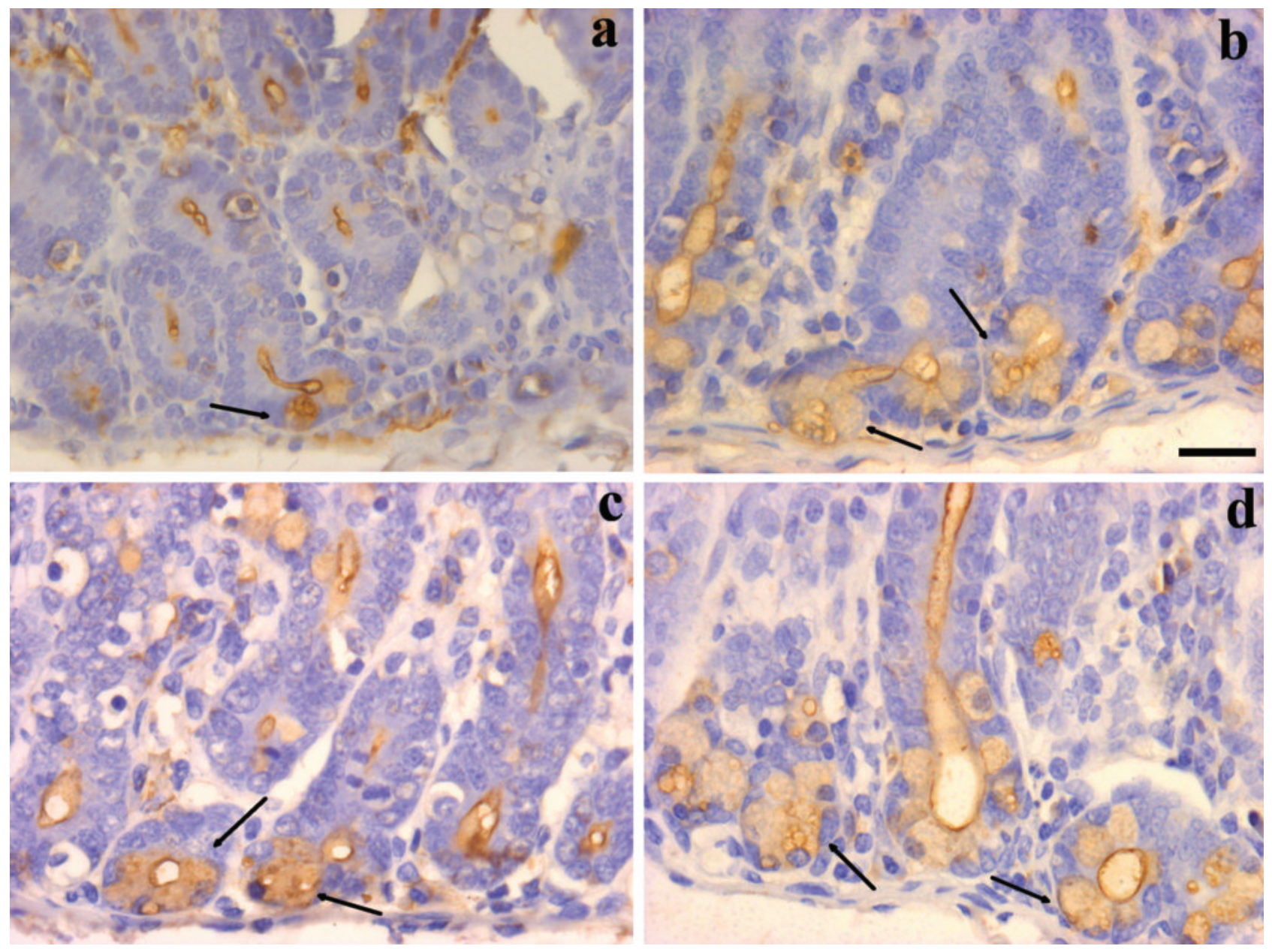

Figure 2. Lectinhistochemical characterisation of Paneth cell granules. (a) Sections incubated with SBA in control and (b) I-30 animals. Note the more heterogeneous labelling of the granules with an intense staining of their periphery (arrows). (c) DBA labelling in control and (d) I-30 Paneth cell. In this case the labelling was also more heterogeneous.
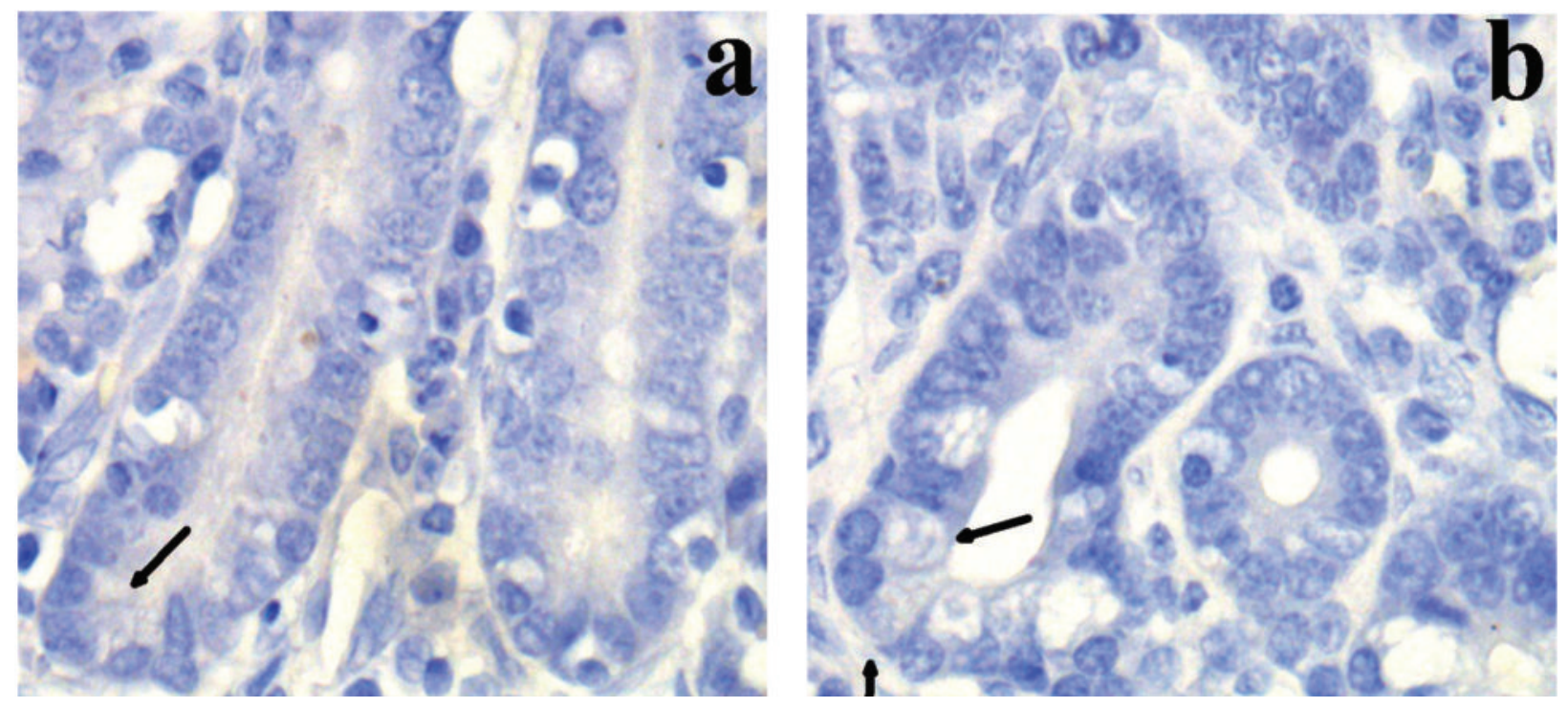

Figure 3. Paneth cell incubated with rabbit polyclonal anti-human lysozyme. Negative immunohistochemical detection in (a) control, and (b) intoxicated animals (arrows). 
their granule composition (Goldstein and Hayes, 1978). The presence of similar oligosaccharides in the glycoprotein composition of Paneth cell granules across different species suggest that these are constitutively expressed conserved glycoproteins. Moreover, their expression in different species, as well as in control and intoxicated rabbits, suggest that they may be essential for Paneth cell granule composition.

Contrary to our expectations, lysozyme (a wellknown Paneth cell granule constituent) was not detected in rabbit Paneth cell granules, either in controls nor in the intoxicated group. Since mouse and human jejunal PC reacted positively the hypothesis of a negative cross-reaction between the employed antibody and rabbit lysozyme was firstly considered. Nevertheless, we employed the same antibody to detect lysozyme in rabbit lachrymal gland, which contains high levels of this enzyme (Thorig et al., 1985). Interestingly, the lachrymal gland epithelial cells were positively stained. The absence of positive immunohistochemical reaction must be interpreted with caution. Further studies must be performed to confirm that rabbit Paneth cell do not contain lysozyme in their granules, or the presence of a particular isozyme which does not react with the currently used antibody (Bonnafus and Raynaud, 1980; Camara and Prier, 1980).

In this study, we observed quantitative, morphologic and morphometric changes in Paneth cells under an experimentally induced intoxication with S. glaucophyllum, although it is yet unreported whether Paneth cells posses vitamin $D$ receptors (VDR).

Responses of Paneth cells to diverse pathological conditions include changes in their number, morphology and in granule composition (Lewin, 1969). Changes in Paneth cell number are most commonly documented. In the small intestine of Trichinella spiralis infected-mice there is an increase in Paneth cell number (Kamal et al., 2001). In some celiac patients, Paneth cells change in number and size (Ehrmann et al., B1990). Paneth cell size can also be modified by sustained hormonal and cytokine stimuli, as it has been previously described under long term exposure to gastrin and cholecystokinin (Balas et al., 1985; Satoh et al., 1989; Porter et al., 2002). It has been reported that in humans afflicted with intestinal bowel disease, necrotizing enterocolitis, acrodermatitis enteropathica and cystic fibrosis (Bevins, 2004) Paneth cells changes were not restricted to number changes only. Most of the morphological and morphometric alterations can be interpreted as Paneth cells responses to various stimuli or the disruption of their metabolic homeostasis due to the absence of specific elements, like zinc (Kelly et al., 2004).

In the present study, a time and dose related increase in Paneth cells number and size was observed in animals intoxicated with S. glaucophyllum. Several studies have shown that 1,25-dihydroxyvitamin D3 have effects on different secretory cells by enhancing peptide synthesis and granule exocytosis (D'Emden and Wark, 1987; Tornquist 1992, Ravid et al., 1993). It has also been reported that chronic hypercalcemia can induce direct stimulatory effects and cause secretory changes in exocrine glandular cells (Layer and Goebell, 1989). Moreover, it has been recently proposed that 1,25dihydroxyvitamin D3 is involved in the activation of intestinal genes related to the mechanisms of endo and xenobiotics detoxification (Kutuzova and DeLuca, 2007).

Taking into account that Paneth cells express detoxifying enzymes such as glutathione S-transferase (Porter et al., 2002), we speculate that this cell population is a target of vitamin $D$, and that the hypertrophy and hyperplasia of Paneth cells observed in this study are a morphologic manifestation of the 1,25-dihydroxyvitamin D3-enhaced secretory and detoxifying ability.

Based on the data presented in this work, Paneth cells were apparently stimulated by S. glaucophyllum intoxication, resulting in their hypertrophy but also their hyperplasia, possibly by inducing stem cells to differentiate along this cell population. Further studies are required to further illuminate the cause of these morphologic changes, the mechanism of excessive levels of 1,25-dihydroxyvitamin $D_{3}$, and the general nature of Paneth cell response to changes in its microenvironment.

\section{Acknowledgements}

The authors wish to express their gratitude to Mrs. Rosa Villegas, Mr. Rubén Mario and Ms. Maria Guadalupe Guidi for their technical assistance. We thank Dr. Bruce Williams, AFIP Dept. of Telemedicine \& Distance Learning, Washington, for skilful assistance in language revision. Financial support was provided in part by grants from Agencia Nacional de Promoción Científica (ANPCyT)(PICT 08-08573), Consejo Nacional de Investigaciones Científicas (CONICET) and Academia Nacional de 
Agronomía y Veterinaria (ANAV), Argentina. All the authors are members of CONICET (Argentinean National Scientific Research Council).

\section{References}

Balas D, Senegas F, Pradayrol L, Vayssette J, Bertrand C, Ribert A. Long-term comparative effect of cholecystokinin and gastrin on mouse stomach, antrum, intestine, and exocrine pancreas. Am J Anat 1985; 174:27-43.

Bancroft JD, Stevens A. Theory and Practice of Histological Techniques, Churchill Livingstone, Edinburgh, 1990.

Bevins CL. Paneth cell and the innate immune response. Curr Opin Gastroenterol 2004;20:572-80

Bikle DD. What is new in vitamin D: 2006-2007. Curr Opin Rheumatol 2007; 19:383-8.

Bonnafus R, Raynaud P. Lysozyme in the material and the digestive secretions of the domestic rabbit. Reprod Nutr Dev 1980;4:1273-8.

Camara VM, Prier DJ. Lysozyme activity in gastrointestinal and lymphoreticular tissues of rabbits genetically deficient in lysozyme. Lab Invest 1980;43:352-7.

Dallorso ME, Gil S, Pawlak E, Lema F, Marquez A. 1,25(OH)2 vitamin D3 concentration in the plasma of Solanum glaucophyllum intoxicated rabbits. Aust Vet J 2001; 79:419-23.

D`emden MC, Wark JD. 1,25-Dihydroxyvitamin D3 enhances thyrotropin-releasing hormone induced thyrotropin secretion in normal pituitary cells. Endocrinol 1987;121:1192-4.

Ehrmann J, Malinsky J, Gregar I. Paneth cells and coeliac disease-quantitative, morphometric analysis. Acta Univ Palacki Olomic Fac Med 1990;126:187-201.

Ergün E, Ergün L Asti RN, Kürüm A. Light and electron microscopic morphology of Paneth cells in the sheep small intestine. Rev Méd Vét 2003:154:351-5.

Evans GS, Chwalinski S, Owen G, Booth C, Singh A, Potten CS Expression of Pokeweed lectin binding in murine intestinal Paneth cells. Epithelial Cell Biol 1994;3:7-15.

Gil S, Dallorso M, Horst R. Screening of vitamin D activity (VDA) of Solanum glaucophyllum leaves measured by radioimmunoassay (RIA). Steroid Biochem Mol Biol 2007;103:483-6.

Gimeno EJ, Portiansky EL, Gomar MS, Costa EF, Massone AM, Alonso $\mathrm{CR}$, et al. Calcinosis in ruminants due to plant poisoning. Contributions on the pathogenesis. In: Acamovic T, Stewart CS, Pennycott T.W eds. Poisonous Plants and Related Toxins. Commonwealth Agricultural Bureau, 2004, pp. 84-9.

Goldstein IJ, Hayes CE. The lectins: carbohydrate-binding proteins of plants and animals. Adv Carbohydr Chem Biochem 1978;35:127340.

Holt P, Arber N, Halmos B, Forde K, Kissileff H, Mc Glynn KA, et al. Colonic epithelial cell proliferation decreases with increasing levels of serum 25-hydroxyvitamin D. Cancer Epidemiol Biomarkers Prev 2002;11:113-9.

Kamal M, Wakelin D, Ouellette AJ, Smith A, Podolsky DK, Mahida YR. Mucosal T cells regulate Paneth and intermediate cell numbers in the small intestine of $T$. spiralis-infected mice. Clin Exp Immunol 2001; 126:117-25.

Kelly PR, Feakins R, Domizio P, Murphy J, Bevins C, Wilson J, et al. Paneth cell granule depletion in the human small intestine under infective and nutritional stress. Clin Exp Immunol 2004;135:303-9.

Kutuzova GD, DeLuca H. 1,25-Dihydroxyvitamin D3 regulates genes responsible for detoxification in intestine. Toxicol Appl Pharmaco 2007;218:37-44.

Layer $\mathrm{P}$, Goebell H. Calcium homeostasis and exocrine pancreas: physiological and pathological interrelations. Schweiz Med Wochenschr 1989; 25:655-63.

Leis 0, Madrid JF, Ballesta J, Hernández F. N- and 0-linked oligosaccharides in the secretory granules of rat Paneth cells: an ultrastructure cytochemical study. J Histochem Cytochem 1997;45:285-93.

Lewin K. The Paneth cell in health and disease. Ann R Coll Sur Engl 1969; 44:23-37.

Mello JRB. Calcinosis - calcinogenic plants. Toxicon 2003; 41: 1-12.

Menard D, Levy E, Delvin EE. Effects of calcitriol on proliferation and differentiation of human fetal jejunum. Biol Neonate 1995; 68:15762.

Müller CA, Autenrieth IB, Peschel A. Innate defenses of the intestinal epithelial barrier. Cell Mol Life Sci 2005; 62:1297-307.

Oestreich B, Strassburger I, Linss W, Geyer G. Quantitative studies on the distribution of Paneth's granular cells in the intestine of golden hamsters and rabbits. Z Mikrosk Anat Forsch 1970;82:236-42.

Ouellette AJ. Paneth cell $\alpha$ defensins: peptide mediators of innate immunity in the small intestine. Springer Semin Immunopathol. 2005; 27:33-146.

Pitha J.The fine structure of membranous inclusions in the Paneth cells of rabbit. Zeitschrift für Zellforschung 1968; 90:563-9.

Porter EM, Bevins CL, Ghosh D, Ganz T. The multifaceted Paneth cell. Cell Mol Life Sci 2002; 59:156-70.

Puche RC, Bingley JB. Calcinosis of Cattle in Argentina. 1ST English edn., Universidad Nacional de Rosario Editora, Rosario, 1995.

Ravid A, Koren R, Maron L, Liberman UA. 1,25- $(\mathrm{OH}) 2 \mathrm{D} 3$ increases cytotoxicity and exocytosis in lymphokine-activated killer cells. Mol Cel Endocrinol 1993; 96:133-9.

Rodning CB, Erlandsen SL, Wilson ID, Carpenter AM. Light microscopic morphometric analysis of rat ileal mucosa: II. Component quantification of Paneth cells. Anat Rec 1982; 204:33-8.

Satoh $Y$, Ishikawa K, Oomori $Y$, Yamano M, Ono K. Effects of cholecystokinin and carbamylcholine on Paneth cell secretion in mice: a comparison with pancreatic acinar cells. Anat Rec 1989; 255:124-32.

Schneider LE, Schedl HP. Effects of Solanum malacoxylon on duodenal calcium binding protein in the diabetic rat. Endocrinology 1977; 100:928-33.

Sinke VG, Geyer G. Untersuchungen über die quantitative verteilung der Panethschen Körnerzellen im Dünndarm von Maus, Ratte und Meerschweinchen. Anat Anz 1968; 123:169-78.

Stevenson RG, Palmer NC, Finley GC. Hypervitaminosis D in rabbits. Case report. Can Vet Jour 1976;17:54-7.

Suda T, Tashimasa S, Takahashi N. The role of vitamin D in bone and intestinal cell differentiation. Annu Rev Nutr 1990;10:195-211.

Takehana K, Masty J, Yamaguchi M, Kobayashi A, Yamada 0, Kuroda M, et al. Fine structural and histochemical study of equine Paneth cells. Anat Histol Embryol 1998;27:125-9.

Taylor C, Shi S, Cote R. Review: Antigen retrieval for immunohistochemistry. Appl Immunohistochem 1996;4:144-66.

Thorig $L$, van Agtmaal EJ, Glasius E, Tan $K L$, van Haeringen NJ. Comparison of tears and lacrimal gland fluid in the rabbit and guinea pig. Curr Eye Res 1985;4:913-20.

Tornquist K. Pretreatment with 1,25-dihydroxycholecalciferol enhances thyrotropin-releasing hormone- and inositol 1,4,5-trisphosphateinduced release of sequestered $\mathrm{Ca}^{2+}$ in permeabilized $\mathrm{GH} 4 \mathrm{Cl}$ pituitary cells. Endocrinol 1992;131:677-81.

Toth D. Ultrastructural changes in Paneth cells during hibernation in the ground squirrel Spermophilus lateralis. Cell Tissue Res 1980; 211:293-301.

Yasui T, Tsukise A, Nara T, Kuwahara Y, Meyer W. Morphological, histochemical and immunohistochemical characterization of secretory production of the ciliary glands in the porcine eyelid. Eur $\mathrm{J}$ Histochem 2006, 50:99-108.

Walling MW, Kimberg DV. Effects of $1 \alpha, 25$-dihydroxyvitamin $D$ and Solanum glaucophyllum on intestinal calcium and phosphate transport and on plasma $\mathrm{Ca}, \mathrm{Mg}$ and $\mathrm{P}$ levels in the rat. Endocrinology 1975; $97: 1567-76$.

Wasserman RH, Henion JD, Haussler MR, McCain TA. Calcinogenic factor in Solanum malacoxylon: evidence that it is 1,25-dihydroxyvitamin D3-glycoside. Science 1976;853-5

Worker NA, Carrillo BJ. "Enteque seco", Calcification and wasting in grazing animals in Argentina. Nature 1967; 215:72-4. 